\title{
Globalization, FDI and Trade in Case Study of Pakistan: An Empirical Analysis
}

\author{
Sabeeha Naseer, Muhammad Shabir Jan \\ Department of Economics, Bacha Khan University Charsadda, Charsadda, Pakistan \\ Email address: \\ sabeeha.naseer@yahoo.com (S. Naseer), Shabir@bkuc.edu.pk (M. S. Jan)
}

\section{To cite this article:}

Sabeeha Naseer, Muhammad Shabir Jan. Globalization, FDI and Trade in case Study of Pakistan: An Empirical Analysis. Journal of Investment and Management. Vol. 10, No. 3, 2021, pp. 38-42. doi: 10.11648/j.jim.20211003.11

Received: May 1, 2021; Accepted: July 8, 2021; Published: July 15, 2021

\begin{abstract}
Globalization is a complex phenomenon that has many national or international implications, as well as various impacts on the national economy and the world economy in general. The process of national economic globalization is clearly influenced by economic performance, foreign trade, financial development and its ability to attract foreign investment. Foreign capital has played a key role in the development of such a state in Pakistan. The current study used the time series data and the data range form 1981-2017. The variables are Globalization, foreign direct investment and trade. study applied ADF unit root test for stationary of these variables. First the unit root test applies at the level the variables are not stationary then apply at first difference so study applied ADF unit root test for stationary. The result shows that all variables are stationary at first difference. However, all variables are not stationary at level. the application of Johansen co-integration test appropriate applied for the purpose of association between variables. Finally, the study applied Vector Error Correction Model (VECM) for the purpose of long run analysis of the study. Johansen co-integration test concluded that globalization have positive impact on FDI and Trade. (VECM) model shows that the Globalization, FDI and Trade have long run relationship.
\end{abstract}

Keywords: Globalization, Foreign Direct Investment, Trade, Johansen Co-integration, VECM

\section{Introduction}

Globalization is a complex phenomenon that has many national or international implications, as well as various impacts on the national economy and the world economy in general. The process of national economic globalization is clearly influenced by economic performance, international trade, financial development and its ability to attract foreign investment. Foreign capital has played a key role in the development of such a state in Pakistan.

Globalization refers to an integrated global economy that includes small trade barriers, unrestricted capitalization, economic labour, and economic activity. According to Lonny and Frederickson [2] a broad finding is that globalization can be described in other ways: "Globalization is very different for different people. For some scholars, globalization is not the end result." Here, we focus internationally on "free trade" and "business openness." It deals with policies that do not involve the government of importing or exporting free trade. The government does not want to consider all taxes and duties on imports and exports; However, it does not follow measures that could harm international trade, such as tariff barriers, quotas and other restrictions.

The FDI promotes the establishment of capital in the host country and serves as an important source of domestic investment [3]. The FDRE economy can support the services sector (eg telecommunications, banking and trade, transport), wholesale and retail, trade and legal services. During this period, there are various differences in the theoretical and literary literature that focus on the relationship between the FDI and the relationship between advanced market and emerging markets.

According to UNCTAD [4], many developing countries, including the least developed, have tried to move from economic independence to a new world, but they have attracted only a small amount of FDI. In addition, a small number of countries have a strong presence in the FDI. The FDI Concept Required investment is mainly used for production to support the economic potential of the product [5]. For Graro and Trevino [6], this explanation helps to understand why most investments go to developed countries, not to developing countries, even though most investments 
are historically marketable. Markets need to compete in order to attract a relatively small amount of FDI compared to a large global FDI.

The current paper provides an analysis of three economic phenomena, namely, globalization, trade and FDI in Pakistan by affirming the relationship between them through economic models.

\section{Literature Review}

Globalization has many important issues: economy (trade, capital flows, financial development); Technology (technology delivery, research and development, information community)). Social (migration, education and health systems, poverty, discrimination); Cultural (freedom, acceptance, tolerance); Political (International and Mass International Cooperation, International Stability and Security).

Dim. S [7] study examines the relationship between globalization, trade openings and foreign direct investment (FDI) in Romania and 25 years. Data from UNCTAD, the World Bank and the KOF Globalization Index were used to examine the relationship between globalization, trade openings and foreign direct investment. In Globalization and FDI. There is a strong and statistically acceptable link between trade openness and FDI and FDI and globalization. In the Romanian economy, these three events are interrelated and each is working to withstand the other's influence. He also emphasized the link between globalization index and foreign direct investment, open trade and market capitalization. These outcomes must be taken into account when developing national policies to attract and export FDI.

Meraj. M [8] investigate the impact of globalization and openness on trade using Bangladesh's economic analysis using the ADRL model and Graggar's reasoning experiment. The key variables used in the study were Transformer Transformation (GIP). They are in the registers, in the business records and in the expense records. Burger Complaint uses Ctor Kutter Automatic Analysis (VAR) method to assess the relationship between Bangladeshi exports and imports in terms of economic growth and globalization (long-term and short-run). Two different methods for testing integration: Johannsson Coalition and Automated Broadcasting (ALA). The ECA and Granger causality test results show a close relationship between GDP and exports. Export shows inflation with foreign trade. However, import donations are not for GDP and exports. This will have a positive impact on trade and economic growth globalization in small developed countries such as Bangladesh (LCC). For those who are willing to open their jobs, this can be an important step in the development process. Exports growth and GIP. Economic growth in. Shows a competitive environment. Accordingly, further foreign exchange policies are recommended as export policies may generate additional foreign exchange to pay import fees and increase capital reserves.

Custorella. F [9] study analyzes the structures of the FDI during the globalization process, using both theological and explicit Chinese as case studies. It is estimated that there have been five changes based on recent literature and economic studies in developing countries and China. These hypotheses suggest that from 1996 to 2007, 30 Chinese provinces were officially. The result is that the FDI reorganization provides some evidence of the international process. The FDI sees economic growth, capital expansion, productivity and job creation, innovation and technology transfer as important factors in emerging economies. The large share of FDI stocks in these economies indicates that foreign economic globalization is driven by the process [10]. In Eastern and Central European countries such as Romania, the purpose of attracting FDI was to facilitate the organization and reorganization of individuals [11]. Developing countries will embrace new technologies, capital development, by eliminating trade barriers, expanding market opportunities for consumers, providing more jobs. Kahai \&Simmons [12]. Internal FDI represents a method of combining national economic products with the world economy [13, 14]. The FDI contributes to trade in developing countries Farsi, Ali and Gohohoz, [15, 16] and makes the domestic FDI economy more open and more conducive to foreign exchange. Nevertheless trade openness has a significant impact on FDI inflows Pradhan. In the case of Romanian economy, globalisation is favourable for economic growth on medium and long term, but could as well, lead to a higher income inequality.

\section{Data and Methodology}

This part of the study contains on theoretical frame, model explanation, and data sources and econometric techniques.

\subsection{Theoretical Frame Work}

\subsubsection{Heckscher-Ohlin Theory}

Smith and Ricardo's concepts did not help them decide which products would benefit the country. Both theories suggest that free and open markets can determine which countries and producers can produce the most productive products. Linn in the early 1900s, two Swedish economists, Eli Hecklers and Beryl Olin, focused on how a country could benefit from comparable production by producing the most abundant products in the country. Their concept is based on the country, production, and capital that invest in plants and equipment. You have determined that the value of any item or property is a function of supply and demand. In terms of demand, the supply was as cheap as the supply, and the supply was high in terms of demand. It is also called the Indicator. Countries, on the other hand, import their short-term resources.

China and India, for example, are cheap, labour-intensive homes. As a result, these countries have become conducive to labour-intensive industries such as textiles and clothing.

\subsubsection{Absolut Advantage Theory}

Lynn in 1776, Adam Smith, under the leadership of The Wealth of Nations, raised an unusual concept London: Will Stratton and K. Recent versions have been changed by scholars and economists. Smith developed a new business concept that focused on making one country more productive than another. "Trade between countries should not be restricted or restricted by government policy or intervention," 
he said. He said trade should be started according to the forces of the natural market. In a hypothetical two-world world, if A is able to produce good cheap or fast (or both) from country B, country A can focus on creating good opportunities. Similarly, if B can do something better, it can focus on special skills. In diversity, countries have the ability to do the same work and create more diversity. The product will be more effective as there is an incentive to create faster and better production methods.

Smith's theory was that increasing efficiency would benefit people in both countries and that trade should be encouraged. According to his theory, the wealth of a country should not be determined by how much gold and silver it should have, but by the way of life of the people.

\subsubsection{The Internalisation Theory for FDI}

This concept seeks to describe the growth of transitional companies and their drive for foreign direct investment. The concept was developed by Buckle and Casson, in 1976 and then by Heinart, in 1982 and Casson in 1983. First, the theory began in 1937 at the national level and in Hymer in 1976 in the natural context. In his first year of doctorate, he received a Ph.D. One was the elimination of the race. Advantages of other companies in a particular activity.

The concept behind the concept is that Buckley and Casson are organizing their internal activities to develop some temporary benefits. It is considered to be very important in the concept of internalizationation used in the theory, but this FDI flows. Hennart develops the concept of internation by developing models of the two types of integration: vertical and horizontal

Hymer is the author of the concept of strict benefits and shows that FDI will only be given priority if certain benefits are greater than the external ones. According to MNE in the end, the market deficit caused the competition to spread. Hymer discusses the cost of information for foreign companies, the treatment of governments, and the threat of money. The result is the same conclusion: Investment Relationships face some adjustment costs when investing abroad. Hymer knew it was FDI step-by-step strategy decision rather than capital-market finance decision-making.

\subsubsection{Globalization Theory}

Awareness of globalization largely depends on the individual It describes the situation and is highly critical. Wow develops the argument that analysts can be classified Based on their position on globalization. However, Dividing is one of the most complex of these There are different opinions on evaluation at the international level. Still Globalization (International, 1999) can be identified by three main points.

\subsubsection{The Hyper Globalist Approach}

presents the stance in the globalisation theory which claims that the world has entered a 'truly global age' legalising the dominance of 'global capitalism'. The logic of hyperglobalist stance is underpinned by 'neo-liberal agenda' which views globalisation 'in terms of open market'.

\subsubsection{The Sceptical Approach}

The effectiveness of marketing sets raises questions And it looks at the issue from a historical perspective. Moreover, skeptics do not see globalization as something new and do not see any change. The world is one. And if so World Trade has been interpreted, and they think that most of the exchanges take place at a foreign level, not around the world. The European Union, the Pacific Rim and other trade can serve as examples.

\subsubsection{The Transformational Approach}

Represents a moderate to moderate approach to globalization. He agrees with geologists about the scope of "global linkages" and the general nature of the process. They, however, question the novelty of the show and see it as a "contradictory process". On the one hand, it promotes economic, cultural, and political incentives, and on the other hand, it makes a difference in the distance from the "Third World". They are getting worse.

\subsection{Data Sources}

The study investigates the relationship among the globalization, FDI, and Trade. The data for FDI and Trade get from world bank and the Globalization data from KOF the data range 1981-2017.

\subsection{Econometric Model}

The model was developed to see the relationship between the Globalization, FDI, Trade.

$$
\mathrm{GLOBt}=\beta+\beta 1 \mathrm{FDIt}+\beta 2 \mathrm{TRADEt}+\mathrm{Ui}
$$

Sources: summon model

Where

GLOB $=$ Globalization

FDI=Foreign Direct Investment

TRADE $=$ Trade

$\mathrm{t}=$ Time series

$\mathrm{Ui}=$ Error Term

\subsection{Econometric Methodology or Statistical Tools}

The current used the statistical tools for the relationship between the Globalization, FDI, Trade the ADF unit root test for the variables, Johansen co-integration for the long run relationship and the vector Error correction model (VECM)

\section{Result and Discussion}

In this part of the study explain the result all variable is stationery at first difference and the Johnson co integration test are applied all the variables are co-integrated then the study used the VECM model

Table 1. Unit root test for Glob, FDI, Trade.

\begin{tabular}{llll}
\hline Variables & ADF (T-statistics) & Critical Values 5\% & Conclusion \\
\hline GLOB & -17.74822 & -2.948404 & I (1) \\
FDI & -3.946556 & -2.948404 & I (1) \\
TRADE & -6.514313 & -2.948404 & I (1) \\
\hline
\end{tabular}


The Augmented Dickey Fuller (ADF) test shows the Stationarity of the variables. ADF test is generally utilized in the field of economics that aspects for the reason to check the stationary of variables. The outcomes of the tests are illustrated in the tabular form. According to the null hypothesis; series has a unit root as it is non-stationary. In conclusion I (1) illustrates that variable is stationary at first difference. In the table explain that all the variables are stationary at first difference.

The table explain the $\mathrm{c} 0$-integration rank test. If there is a* on zero, then this shows that there is no co-integration but if * is on At Most so this means that co-integration occurs.

Table 2. Johansson Co-Integration Test.

\begin{tabular}{|c|c|c|c|c|}
\hline $\begin{array}{l}\text { Trend Assumption: Linear d } \\
\text { Series: GLOB, FDI, TRADE } \\
\text { Lags Interval (in first differe } \\
\text { Unrestricted Co-integration }\end{array}$ & $\begin{array}{l}\text { tic trend } \\
\text { to } 1 \\
\text { (Trace) }\end{array}$ & & & \\
\hline Hypothesized No. of CE (s) & Eigenvalue & Trace Statistic & 0.05 Critical Value & Prob.** \\
\hline None* & 1.000000 & 742.9809 & 29.79707 & 0.0001 \\
\hline At most 1 & 0.189187 & 10.18849 & 15.49471 & 0.2665 \\
\hline At most 2 & 0.078158 & 2.848352 & 3.841466 & 0.0915 \\
\hline
\end{tabular}

Trace test indicates 1 co-integration eqn (s) at the 0.05 level

*denotes rejection of the hypothesis at the 0.05 level

**MacKinnon-Haug-Michelis (1999) p-value

Maximum rank zero, Maximum rank one, Maximum rank two.

At maximum rank zero, the trace statistic (742.9809) exceeds critical values (29.79707). Therefore, reject the null hypothesis so that the time series variables GLOB, FDI and TRADE are co-integrated. And the maximum rank one shows the trace statistic (10.18849) does not exceed critical values (15.49471). Therefore, accept the null hypothesis that there is co-integration of one equation. Thus, as per maximum rank one, GLOB, FDI, TRADE are co-integrated of one equation. The maximum rank two, the trace statistic (2.848352) does not exceed critical values (3.841466). Therefore, accept the null hypothesis that there is cointegration of two equations. Thus, as per maximum rank two, GLOB, FDI, TRADE are co-integrated.

Table 3. VECM model.

\begin{tabular}{llll}
\hline Error Correction: D (GLOB) & & & \\
\hline & D (GLOB) & D (FDI) & D (TRADE) \\
\hline & $2.56 \mathrm{E}-10$ & -0.550943 & $8.22 \mathrm{E}-11$ \\
Co-Integration 1 & $-2.40 \mathrm{E}-10$ & -0.16376 & $-2.60 \mathrm{E}-10$ \\
& {$[1.08315]$} & {$[-3.36430]$} & {$[0.31095]$} \\
& 772.3241 & $1.00 \mathrm{E}-07$ & $-3.40 \mathrm{E}-07$ \\
D (GLOB (-1)) & -810.819 & $-1.20 \mathrm{E}-06$ & $-1.30 \mathrm{E}-06$ \\
& {$[0.95252]$} & {$[0.08564]$} & {$[-0.25941]$} \\
& 360.2702 & $-2.60 \mathrm{E}-09$ & $-3.59 \mathrm{E}-07$ \\
D (GLOB (-2)) & -546.118 & $-7.90 \mathrm{E}-07$ & $-8.80 \mathrm{E}-07$ \\
& {$[0.65969]$} & {$[-0.00331]$} & {$[-0.40673]$} \\
& 0.48764 & $-3.97 \mathrm{E}-11$ & $2.60 \mathrm{E}-10$ \\
D (FDI (-1)) & -0.16685 & $-2.40 \mathrm{E}-10$ & $-2.70 \mathrm{E}-10$ \\
& {$[2.92265]$} & {$[-0.16510]$} & {$[0.96516]$} \\
& 0.13965 & $-4.14 \mathrm{E}-11$ \\
D (FDI (-2)) & -0.19668 & $-1.21 \mathrm{E}-10$ & $-3.20 \mathrm{E}-10$ \\
& {$[0.71004]$} & $-2.80 \mathrm{E}-10$ & {$[-0.13042]$} \\
& $1.41 \mathrm{E}+08$ & {$[-0.42761]$} & -0.058756 \\
D (TRADE (-1)) & $-1.30 \mathrm{E}+08$ & -0.015134 & -0.21515 \\
& {$[1.05514]$} & -0.19198 & {$[-0.27309]$} \\
& -71194684 & {$[-0.07884]$} & 0.278228 \\
D (TRADE (-2)) & $-1.30 \mathrm{E}+08$ & 0.129668 & -0.21265 \\
& {$[-0.54067]$} & -0.18974 & {$[1.30841]$} \\
& -14400608 & {$[0.68339]$} & -0.018859 \\
C & $-1.10 \mathrm{E}+08$ & 0.547379 & -0.18381 \\
& {$[-0.12652]$} & -0.16401 & {$[-0.10260]$} \\
\hline
\end{tabular}

R-squared: 1.036+19Adj. R-squared: 0.332485 Sum sq. residuals: 0.474079

The above table shows the vector error correction estimations. In the table this bracket ( ) shows standard errors, the [ ] values indicate t- statistic bracket. The dependent variables are GLOB, foreign direct investment FDI and
TRADE. The first variable is GLOB and the Coint equation 1 of D (GLOB) is 2.5610 and t-statistic is 0.550943 , so the positive value of coint equ1 and significant value of t-statistic shows that there is a long run association between 
globalization, FDI and Trade. similar results were documented by (Stela Dima (2016)) and ((Panagiotis. G et al) (2011)) The second FDI (-1) and FDI (-2) the third is TRADE (-1) and TRADE (-2).

\section{Conclusion}

Globalization is a complex phenomenon that has many national or international implications, as well as various impacts on the national economy and the world economy in general. The process of national economic globalization is clearly influenced by economic performance, international trade, financial development and its ability to attract foreign investment. Foreign capital has played a key role in the development of such a state in Pakistan. The current study used the ADF unit root test for stationary. The result shows that all variables are stationary at first difference. However, all variables are not stationary at level. the application of Johansen co-integration test appropriate applied for the purpose of association between variables. Finally, the study applied Vector Error Correction Model (VECM) for the purpose of long run analysis of the study. Johansen cointegration test concluded that globalization have positive impact on FDI and Trade. (VECM) model shows that the Globalization, FDI and Trade have positive long run relationship.

The current study on restrictions was limited to Pakistan because it focused on Pakistan. Accordingly, further research can be done by combining other variables, taking into account the purpose and interests of the experts. Overall, the current study aims to encourage future scholars in the region to shed more light on globalization and the impact of the FDI on other groups and economic flows around the world.

\section{References}

[1] Aizenmann, J. and Noy, I. (2006). FDI and trade-Two-way linkages?. The Quartely Review of Economics and Finance, 46 (3), pp. 317-337.

[2] Al-Shawaf, A. M. K. \& Almsafir, M. K. (2016). Economic globalization: role of inward and outward FDI with economic growth-Evidence from Malaysia. Journal of Business and Retail Management Research, Vol. 10 Issue 2, pp. 64-74.

[3] Dima, S. (2016). Globalisation, trade openness and foreign direct investment in Romania. Studia Universitatis Vasile Goldiş, Arad-Seria Ştiințe Economice, 26 (4), 41-53.

[4] Meraj, M. (2013). Impact of globalization and trade openness on economic growth in Bangladesh. Ritsumeikan Journal of Asia Pacific Studies, 32, 40-50.

[5] Kumar, N. (2002). Globalization and the quality of foreign direct investment. Oxford UnivPr.

[6] Liargovas, P. G., \& Skandalis, K. S. (2012). Foreign direct investment and trade openness: The case of developing economies. Social indicators research, 106 (2), 323-331.

[7] Custorella, F. (2017). The impact of globalization on FDI: An empirical analysis of the FDI determinants in China.

[8] Kornecki, L. \& Rhoades, D. (2007). How FDI facilitates the globalisation process and stimulates economic growth in CEE. Journal of International Business Reserch, Vol. 6, No. 1, pp. 113-126.

[9] Heimann, B. (2003). Tax incentives for Foreign Direct Investment in the Tax Systems of Poland, the Netherlands, Belgium and France. Available at: http://www.iwim.unibremen.de/publikationen/pdf/b074.pdf Accessed 30 June 2016.

[10] Kahai, S. K. \&Simmons, W. (2005). The impact of Globalization on income inequity. Global Business and Economics Review, Vol. 7, No. 1, pp. 1-15.

[11] Adams, S. (2008). Globalization and income inequality: Implications for intellectual propertyrights. Journal of Policy Modeling, 30 (5), pp. 725-735.

[12] Méon, P. G. and Sekkat, K. (2007). Revisiting the relationship between governance and foreign direct investment. Brussels Economic Review, 50 (1), pp. 41-61.

[13] Fadhil, M. A. and Almsafir, M. K. (2015). The Role of FDI Inflows in Economic Growth in Malaysia (Time Series: 19752010). Procedia Economics and Finance, 23, pp. 15581566.

[14] Farshid, P. Ali, S. and Gholamhosein, S. (2009). The impact of foreign direct investment and trade on economic growthTaking China, Korea, Malaysia, Philippines \& Thailand for example. China-USA Business Review, 8 (12), pp. 37-43.

[15] Mutascu, M. and Fleischer, A.-M. (2011). Economic Growth and Globalization in Romania. World Applied Sciences Journal, 12 (10), pp. 1691-1697.

[16] Neagu, O. (2014). How much does globalisation affect the income inequality in Romania?. Studia Universitatis "Vasile Goldis” Arad, Economics Series, Vol. 24, Issue 4, pp. 76-83. 